\title{
Ophthalmologic screening of children of public schools in Belo Horizonte/MG: an overview about the visual impairment in children
}

\section{Avaliação oftalmológica de crianças de escolas públicas de Belo Horizonte/MG: um panorama acerca da baixa acuidade visual}

Geraldo de Barros Ribeiro', Amanda Lopes Dias Coelho², Pedro Henrique Pinheiro Chaves², Rafhael de Lima Macedo², Thiago Augustus Blasco e Silva ${ }^{2}$

\begin{abstract}
Objectives: To describe and analyze the prevalence of visual impairment and its causes in public school students in Belo Horizonte/MG (Brazil). Methods: Cross-sectional study of 1452 public school children from 5 to 19 years old, in Belo Horizonte/MG (Brazil), screened and evaluated between 2011 and 2014. Results: Of the total sample, 150 patients (10,33\%) had low visual acuity at the screening, and were referred to an ophthalmologist to further examination. Forty (26\%) of the referred patients presented at the ambulatory, where 29 $(72,5 \%)$ of these showed indication of visual correction. Simple and compound myopic astigmatism were the most frequent diagnoses associated with prescription glasses. Conclusion: The study showed that the prevalence of visual impairment in this population were consistent with other similar programs. By contrast, the abstention rate was much higher than the expectation, showing the importance of preventive and informative actions about the eye health care.
\end{abstract}

Keywords: Visual acuity; Child; Prevalence; Refraction; Ocular health

\section{RESUMO}

Objetivos: Descrever e analisar a prevalência de baixa acuidade visual e suas causas em estudantes do ensino público de Belo Horizonte/MG. Métodos: Estudo transversal de 1452 escolares de 5 a 19 anos, do ensino público de Belo Horizonte/MG, triados e atendidos entre 2011 e 2014. Resultados: Da amostra total, 150 pacientes (10,33\%) apresentaram baixa acuidade visual à triagem, recebendo encaminhamento para atendimento oftalmológico. Quarenta $(26,66 \%)$ dos encaminhados compareceram à consulta, onde 29 (72,5\%) desses apresentaram indicação de correção visual. O astigmatismo miópico simples e composto foram os diagnósticos mais relacionados à prescrição de óculos. Conclusão: $\mathrm{O}$ estudo mostrou que a prevalência de baixa acuidade visual na população estudada foi compatível com demais programas semelhantes. Em contra partida, a taxa de abstenção foi maior do que o esperado, evidenciando a importância da criação de medidas preventivas e informativas quanto à importância do cuidado com a saúde ocular.

Descritores: Acuidade visual; Criança; Prevalência; Refração; Saúde ocular

\footnotetext{
1,2 Centro Universitário de Belo Horizonte (UniBH) (MG), Brazil

Institution where it was held: University Center of Belo Horizonte, Belo Horizonte, MG, Brazil.
}

The authors declare no conflicts of interest

Received for publication 24/03/2015 - Accepted for publication 12/05/2015

Rev Bras Oftalmol. 2015; 74 (5): 288-91 


\section{INTRODUCTION}

$\mathbf{T}$ The sight is responsible for most of the sensory stimuli we have in life. In addition, it is mainly through these stimuli that the learning process takes place.

The World Health Organization estimates that more than 161 million people worldwide are blind or have some visual impairment. However, it is known that $80 \%$ of these cases are treatable or could have been prevented. Such visual affections influence negatively the economic and social aspects of the individuals affected. (1)

It is known that among the pediatric population affected by low visual acuity there is a significant amount of children suffering from any eye disease, refracional or not, that influences directly their quality of life and school performance. ${ }^{(2)}$ Statistical studies are made with this group of patients, showing rates ranging from $8 \%$ to $34 \%$ of visual impairment. ${ }^{(3-10)}$

The wide range of prevalence of visual difficulties in children and adolescents among several studies is explained by the population, temporal and methodological differences. It is known, for example, that these indexes are higher in patients at highrisk groups, such as low-income families. ${ }^{(11)}$

The screening and examination of children and youngsters with low visual acuity is important because it enables early identification of eye problems and contributes to the prevention of permanent damage to vision. In addition, it enables the analysis of the prevalence of these problems in the studied population and contributes to the better planning of public health programs aimed at the eye health.

\section{ОвJECTIVE}

The objective of the present study was to measure the visual acuity of children and youngsters from the public education system of Belo Horizonte/MG, and refer those with low visual acuity for a complete eye examination to be held at the University Center of Belo Horizonte (UniBH).

\section{Methods}

The research is part of a cross-sectional study for detection of prevalence of refractive errors or other causes of reduced visual capacity in students from public schools in the city of Belo Horizonte (MG).

The research protocol was approved by the Research Ethics Committee of the University Center of Belo Horizonte (UniBH), CAAE: 37007614.2.0000.5093.

The visual acuity was measured in children and adolescents between 5 and 18 years old regularly enrolled in 11 public schools in Belo Horizonte/MG between November 2011 and November 2014. Those responsible for the measurement of visual acuity of students were the medicine students of the University Center of Belo Horizonte, who were authorized and supervised by an ophthalmologist.

The measurements were made with an optometric scale of Snellen, which was positioned in a large and bright environment 6 meters from the student examined. Each eye is tested separately and, in the case of a child wearing glasses, the test was first performed without the use of lenses and then with them. The value registered in the study corresponded to the last row of the table in which the student has identified more than half of the optotypes presented.

The students who demonstrated low visual acuity (vision below 0.7 or $20 / 30$ in at least one eye) were referred for complete eye exam in the ambulatoiesy of the University Center of Belo Horizonte (UniBH). The exam was conducted by an ophthalmologist at no cost to parents.

It is important to note that the methodology used for the evaluation of visual acuity of children demanded the student's cognitive ability, and therefore there was the impossibility of screening some students due to some intellectual disorder that limited the ability to understand the measurement proposed.

The students referred were examined for their ophthalmologic and systemic complaints that might affect the visual system. Moreover, the personal and family history of preceeding eye problems was checked. Subsequently, a new measurement of visual acuity, static refraction, measurement of the point near convergence, stereopsis, ocular motility, orthoptic test, slit lamp examination and fundoscopy was conducted.

The students examined with due indication of use of visual correction received the prescription. At the end of the program, the prevalence of visual impairment in this population was calculated, as well as the various nosological entities found.

\section{Results}

Of the total of 1452 children and adolescents subjected to the screening examination, $733(50.48 \%)$ were female and 719 (49.51\%) male. Graph 1 discriminates schoolchildren assessed according to the age group, which ranged from 5 to 18 years old.

\section{Graph 1}

Distribution of students assessed according to the age group $0506 \ldots 1718$ years

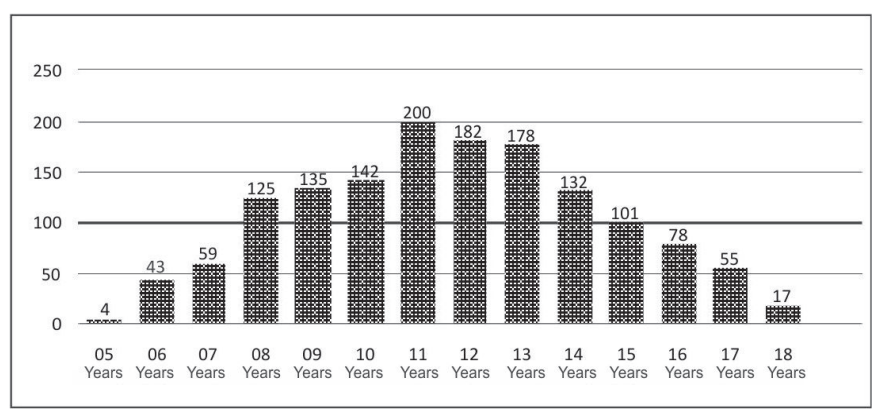

Da amostra total, 150 crianças e adolescentes (10,33\%) apresentaram baixa acuidade visual (menor do que 0,7 ) em ao menos um dos olhos, sendo encaminhados para o atendimento oftalmológico.

Among the 1302 remaining students, 1287 (88.32\% of total) did not present low visual acuity, being taught on the importance of periodic ophthalmologic revaluation. Other 15 children $(1.13 \%$ of total) had their assessment undermined by neurological issues and the lack of understanding required for the exam.

From the 150 students referred, 40 students $(26.66 \%)$ attended the ambulatiry appointment, with the diagnosed causes of reduced visual acuity being: myopia associated to astigmatism, isolated astigmatism, hyperopia, isolated myopia, 
amblyopia, strabismus, anisometropia and low central visual acuity.

Table 1 shows the prevalence of the refractive diagnostics in the students present in the ambulatory of the University Center of Belo Horizonte (UNIBH).

Table 1

Distribution of refractive error diagnosis

\begin{tabular}{lll}
\hline Diagnosys & N & \% \\
\hline Physiological hyperopia ( $\geq 3$ diopters) & 11 & 27,5 \\
Compound myopic astigmatism & 9 & 22,5 \\
Simple myopic astigmatism & 8 & 20 \\
Hyperopia (> 3 diopters) & 5 & 12,5 \\
Myopia & 4 & 10 \\
Compound hyperopic astigmatism & 3 & 7,5 \\
\hline Total & $\mathbf{4 0}$ & $\mathbf{1 0 0}$ \\
\hline
\end{tabular}

Of the students attending the ambulatory appointment, 29 students $(72.5 \%)$ received a prescription for visual correction. The other 11 students assessed did not require prescription of visual correction due to physiological hypermetropia ( $£ 3$ diopters), which according to reports from patients and parents did not generate any functional and/or learning disorders, thus not being necessary to correct it.

Analyzing the 40 students examined in the ambulatory, it was possible to diagnose 13 of them with other ophthalmologic disorders associated to the refractive errors described in table 1. Table 2 demonstrates the prevalence of these associated diagnoses.

Table 2

Distribution of the other diagnoses

\begin{tabular}{lll}
\hline Diagnosys & $\mathbf{N}$ & $\mathbf{\%}$ \\
\hline Anisometropia & 4 & 10 \\
Amblyopia & 3 & 7,5 \\
Strabismus & 3 & 7,5 \\
Allergic conjunctivitis & 2 & 5 \\
Low central visual acuity* & 1 & 2,5 \\
\hline Total of exams & & $\mathbf{N}=\mathbf{4 0}$
\end{tabular}

* The student had mild cerebral palsy due to prematurity.

The general diagnosis, including isolated and associated cases, mostly found were the compound myopic astigmatism $(22.5 \%)$, simple myopic astigmatism $17(20 \%)$, followed by hyperopia 16 (40\%), myopia 4 (10\%), and compound hyperopic astigmatism $(7.5 \%)$.

\section{Discussion}

A literature review was carried out from the year of 1980, in which similar studies were also conducted in children and youngsters from public schools in different cities in Brazil. (3-10)
Graph 2 shows the comparison between the different prevalences found, ending with the rate found in the present study, which was similar to most national statistics.

\section{Graph 2}

\section{Prevalences of low visual acuity in schoolchildren from public schools in Brazil}

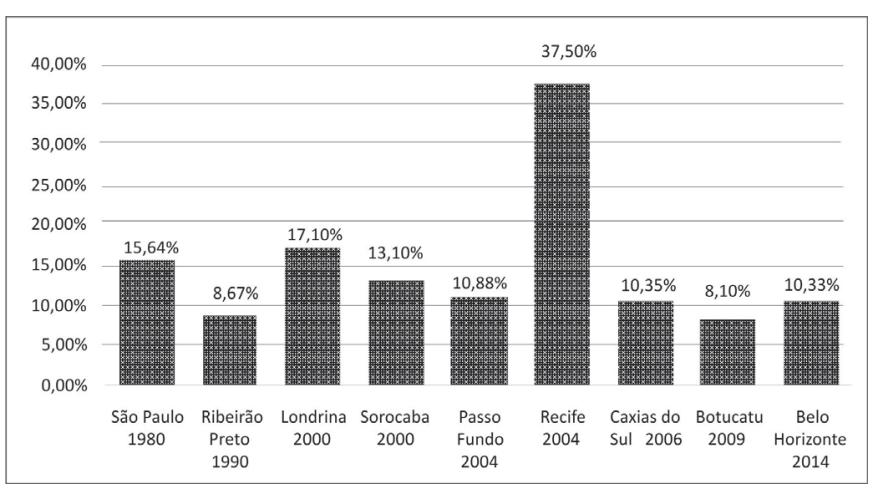

Even with measures such as sending a letter to the parents of the 150 students referred and contacting the families by telephone to explain the importance of the exam and clarify any doubts, $26.66 \%$ (40 patients) came to the appointment. The low adhesion in such programs is common, and the most common causes for this fact addressed in the literature are: access to health insurance, difficulty in transportation and loss of a workday. ${ }^{(12)}$ However, the adhesion rate found in the present study was lower to others listed in the graph 3 . We believe that the fact that the screening was conducted in schools whereas the eye examination was in the UniBH ambulatory made it difficult for parents to go, despite the tests are scheduled on Saturdays. The best option would be to perform the eye exams at school, without the need of the student movement.

All the 40 students $(100 \%)$ referred and seen in the ambulatory presented some king of refractive change in the visual organ, this being associated to some other condition, ophthalmologic or not. The isolated refractive error mostly found in our study was the physiological hyperopia. However, the three refractive diagnoses mostly related to the prescription for vision

\section{Graph 3}

\section{Adhesion rates in children and youngsters selected to take part in a free eye examination in national studies}

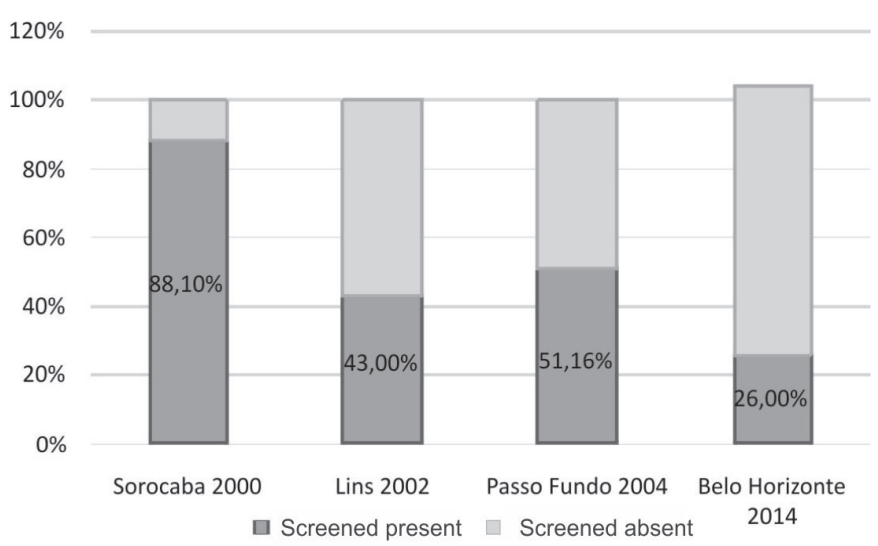


correction were: compound myopic astigmatism, simple myopic astigmatism, and hyperopia. Such diagnostic prevalence was also similarly found in several similar studies conducted in Brazil, like the ones in Passo Fundo ${ }^{(7)}$ and Botucatu ${ }^{(10)}$. The two studies aforementioned showed the hyperopic astigmatism as the most prevalent diagnosis. In General, the isolated or associated diagnoses mostly found in the students were: astigmatism (50\%), followed by hyperopia (47.5\%) and myopia (32.5\%), which is repeated in several other Brazilian studies. ${ }^{(3,7,10,13,14)}$

Low visual acuity, especially in school, is a factor for learning difficulties. The evaluation of school performance of children with low visual acuity has not been object of study in the present study, but the association between low school performance and low visual acuity is reported in several studies. (14-16) The identification of low visual acuity due to low visual development, amblyopia, must have an early diagnosis, because the sensory plasticity period ends at the end of childhood.

Of the 11 schools visited, only 1 had been visited by ophthalmologists from the public services, and the teachers were trained to make the screening using the Snellen scale. The other $10(90 \%)$ schools visited did not visually screen their students, and the teachers were not trained for conducting such screening. These results confirm the unpreparedness of these institutions in dealing with possible visual problems presented by their students.

Campaigns and training of teachers to carry out visual screening in the students, like the campaign from the Ministry of education entitled "olho no olho" have proved effective in increasing the rates of diagnosis and treatment of visual disorders in school children. ${ }^{(17,18)}$

\section{Conclusion}

The study showed that part of the population studied (children and youngsters from public schools in Belo Horizonte) fulfilled the screening criteria and was referred to a complete ophthalmologic assessment in searching a cause for low visual acuity. Of the students examined, the majority had a prescription for visual correction.

A portion of the students referred for complete eye exam did not go to the ophthalmology ambulatory. This reinforces the importance of planning preventive actions directed to eye health in the region, as well as taking actions for parental awareness.

The large number of schools unprepared to deal with the vision problems of their students highlights the importance of public and/or private policies aimed at training the teachers of the public schools in Belo Horizonte. Campaigns such as "olho no olho" of the Ministry of Education have already proved effective, and should be continued or used as an example for future actions in public schools.

\section{REFERENCES}

1. Resnikoff S, Pascolini D, Etyaále D, Kocur I, Pararajasegaram R, Pokharel G, Mariotti S. Global data on visual impairment in the year 2002. Bull World Health Organ. 2004,82(11):844-51.

2. Alves MR, Temporini ER, Kara-José N. Atendimento oftalmológico de escolares do sistema público de ensino no município de São Paulo: aspectos médico-sociais. Arq Bras Oftalmol. 2000,63(5):359-63.

3. Cano MA, Silva GB. Detecção de problemas visuais e auditivos de escolares em Ribeirão Preto: estudo comparativo por nível socioeconômico. Rev Latinoam Enfermagem. 1994,2(1):57-68.

4. Gaete MIL, Lira RP, Moraes LF, Vasconcelos MS, Oliveira CV Associação entre a necessidade de prescrição de correção óptica e outras doenças oculares em crianças na idade escolar. Arq Bras Oftalmol. 2007,70(6):949-52.

5. Kara-José N,Temporini ER. Avaliação dos critérios de triagem visual de escolares de primeira série do primeiro grau. Rev Saúde Pública. 1980,14(1):205-14.

6. Lopes GJA, Casella AM, Chuí CA. Prevalência de acuidade visual reduzida nos alunos da primeira série do ensino fundamental das redes pública estadual e privada de Londrina-PR, no ano de 2000. Arq Bras Oftamol. 2002,65(1):659-64

7. Estacia P,Stramari LM, Schuch SB, Negrello D, Donato L. Prevalência de erros refrativos em escolares da primeira série do ensino fundamental da região nordeste do Rio Grande do Sul. Rev Bras Oftalmol. 2007; 66(5):297-303.

8. Gianni RJ, Mais E, Coelho EC, Oréfice FR, Moraes RA. Prevalência de baixa acuidade visual em escolares da rede pública, Sorocaba. Revista de Saúde Pública. 2004;38(2):201-8.

9. Simionato EZ, Soldera J, Pires EM, Bassani FR, Rizzon ES, Poleto GB. Sinais e sintomas relacionados à baixa acuidade visual em escolares do nordeste do Rio Grande do Sul. Rev Bras Med Fam Comun. 2007;3(9):38-44.

10. Oliveira CA. Erros de refração como causas de baixa visual em crianças da rede de escolas públicas da regional de Botucatu-SP. Arq Bras Oftalmol. 2009,72(2):194-8.

11. Frick DJ, Olitsky SE, Campbell A, Glaros AG. Ocular problems in low-income and minority children. J Pediatr Ophtalmol Strabismus. 2013,50(6):363-8.

12. Abud A, Ottaiano JA. Aspectos socioeconômicos que influenciam no comparecimento ao exame oftalmológico de escolares com alterações visuais. Arq Bras Oftalmol. 2004,67(5):773-9.

13. Garcia CA, Oréfice F, Nobre GF, Souza DB, Rocha ML, Vianna RN. Prevalence of refractive errors in students in Northeastern Brazil. Arq Bras Oftalmol. 2005;68(3):321-5.

14. Toledo C, Paiva A, Camilo G, Maior M, Leite I, Guerra M. Detecção precoce de deficiência visual e sua relação com o rendimento escolar. Rev Assoc Med Bras. 2010,56(4):415-9.

15. Silva C,Almeida DR, Bernardes RR, Bazzano CO, Mesquita Filho M, Magalhães CH, Atzingen DA. Desempenho escolar: interferência da acuidade visual. Rev Bras Oftalmol. 2003,72(3):168-71.

16. Brito PR, Veitzman S. Causas de cegueira e baixa visão em crianças. Eye. 1992;6(2):173-6.

17. Carvalho R, Temporini ER, Kara-José N. Avaliação de atividades de campanha de saúde ocular na escola: percepção de professores. Arq Bras Oftalmol. 2007,70(2):239-45.

18. Russ HH,Temporini E, Kara-José N. Impacto da Campanha Olho no Olho em escolas de ensino fundamental - Percepção pessoal de ensino. Arq Bras Oftalmol. 2004,67(2):311-21.

\section{Corresponding author:}

Geraldo de Barros Ribeiro

Rua Desembargador Jorge Fontana, 476 - Cj 601/605 -

Belvedere

Belo Horizonte/MG - ZIP Code: 30320-670

E-mail: gbarrosribeiro@gmail.com 